Indonesian Science Education Research
(ISER)

\title{
THE EFFECT OF COOPERATIVE LEARNING MODELS: GROUP INVESTIGATION (GI) MODEL TOWARDS STUDENTS LEARNING RESULTS ON THE SUBJECT MATTER GAS KINETIC IN SENIOR HIGH SCHOOL 18 MEDAN SEMESTER II ACADEMIC YEAR 2016/2017
}

\author{
Ayu Lestari ${ }^{1 *}$, Mariati Purnama Simanjuntak ${ }^{2}$, and Wijayanti Wijaya ${ }^{2}$ \\ ${ }^{1}$ Department of Physics Faculty of Mathematics and Natural Sciences, Medan State University \\ ${ }^{2}$ Science Department Faculty of Mathematics and Natural Sciences, Medan State University \\ St. Williem Iskandar Psr. V Medan Estate, Medan, Indonesia, 20221 \\ *yulestari2307@gmail.com
}

Accepted: November $11^{\text {th }}, 2019$. Published: November $26^{\text {th }}, 2019$

\begin{abstract}
This study aimed to determine the effect of using cooperative learning model which was Group Investigation (GI) model toward the student learning results on the subject matter Kinetic Theory of Gas Class XI Semester II Senior High School 18 Medan Academic Year 2016/2017. This kind of research was quasi-experiment with two group pre-test and post-test design. The population in research is all of students class XI Senior High School Negeri 18 Medan consists of 4 class. The sample of the research was taken by two classes determined by random sampling technique, that is class XI MIPA-2 using cooperative group investigation model type with number of students is 24 people and class XI MIPA-3 using conventional learning with number of students is 27 people. The research instrument in the form of an essay test was eight matter - data analysis techniques used by normality test, homogeneity test and different test (t-test). The results of data analysis there is the influence of cooperative learning model: group investigation type toward the resulting student learning on the subject matter Kinetic Theory of Gas in class XI Senior High School 18 Medan, Academic Year 2016/2017.
\end{abstract}

Keywords: cooperative learning model type group investigation, the result of student learning, kinetic theory of gas. 


\section{Introduction}

Education is a human effort to foster his personality undervalues in society and culture. Regulation number 20 of 2003 "Education is a conscious and planned effort to create a learning atmosphere and learning process so that students actively develop their potential to have spiritual strength, selfcontrol, personality, intelligence, noble character and skills needed by themselves, society, nation and country". The progress of a nation is determined by the level of success in education. The success of education will be achieved by a nation if there is an effort to improve the quality of education of the nation itself (Purwanto, 2014: 18).

The main problem in learning in formal (school) education currently is the low absorption and interest of students in learning. This can be seen from the average student learning outcomes which are still very alarming. This achievement is certainly the result of learning conditions that are still conventional and does not concern the reality of the learners' own dimensions, namely how they actually learn (learning to learn). A more substantial meaning, that the learning process to this day still provides teacher dominance and does not provide access for students to develop independence through discovery in their thought processes (Trianto, 2010: 5).

This fact is in accordance with the results of observations conducted by researchers at SENIOR HIGH SCHOOL 18 Medan in February 2017 by giving an instrument in the form of a questionnaire to 24 students. The results of the questionnaire distributed were obtained data that $87.5 \%$ of students said that physics was a mediocre lesson while $12.5 \%$ of students said they did not like physics. During the learning process, students rarely ask questions and express their opinions to the teacher, $65 \%$ of students say so.

The biggest reason students say so is that they are less interested in learning and lack courage in expressing opinions and they are rarely involved when the learning process takes place or is only teacher-centered. Classroom learning takes place by recording and working on problems. Such learning is the cause of the unsatisfactory results of student physics learning obtained in the Semester
Final Examination on academic year of $2016 / 2017$, as many as $45 \%$ of students can meet the passing score standard, which is 70 . Students say they prefer to study in discussions with other friends in learning and solve problems that are considered difficult to resolve as much as $79.1 \%$. Generally, students want to learn with the use of demonstration or practicum methods because of the curiosity of many students and also want to do proof of concepts and physical material facts so that students have an interest or interest in participating in classroom learning.

The model that makes students learn collaboratively is needed to reduce the occurrence of boredom learning physics in students and foster students' interest in learning. Students active in the learning process will make learning more meaningful because participants play an important role in constructing their knowledge. One learning model that can be used to overcome the problems described above, the author, in this case, uses the GI type cooperative learning model.

The cooperative learning model type investigation group is one of the cooperative learning models where students collaboratively in their groups examine, experience and understand the topic of the material to be studied. This cooperative model has the benefit of training students to accept differences of opinion and work in conducting investigations to solve problems together with other students with different backgrounds (Joyce et al., 2011: 310).

According to previous researchers, Afdalita and Purwanto (2015: 201) found that physics learning outcomes of students who were given learning with the GI type of cooperative learning individually as many as 15 people by $50 \%$ were complete, and the rest is not yet complete. However by using conventional teaching as many as 8 people individually, $26.6 \%$ is complete, and the rest is not yet complete. It was concluded that using cooperative learning model type group investigation can improve student learning outcomes in the classroom.

The main material of the Kinetic Theory of Gas students is required to imagine how particles move, how the temperature, volume, amount of matter and pressure influence, so students are required to think 
more highly. PhET simulations are very effective to help students build understanding and intuition for abstract phenomena. One example of media that can help explain the nature of abstract material is PhET virtual media. This simulation is right for use in the material of Gas Kinetic Theory due to the abstract nature of the material.

One of the existing virtual laboratory programs in Physics Education Technology or PhET which was developed by the University of Colorado at Boulder in order to provide a virtual laboratory-based learning simulation that allows teachers and students to use for physics learning in the classroom. Physics Education Technology (PhET) Simulation is interactive physics simulation software available on the site that can be downloaded for free and can be run online or offline (Yuafi and Endryansyah, 2015: 410).

The use of PhET media in this study is to help students understand visual concepts and to demonstrate the material. PheT simulation brings to life what is not visible to the eye through the use of graphics. PheT is easy to use and apply in the classroom (Sumargo and Yuanita, 2014: 120). This was supported by previous researcher Kamaruddin (2016: 39) stated that "The application of Virtual PhET laboratory media in the material of Kinetic Gas Theory can improve student learning outcomes. It was seen from the achievement of individual completeness values of $75 \%$ in the first cycle to $84 \%$ in the second cycle and increased again to $97 \%$ in the third cycle. Similarly, classical completeness increased from $60 \%$ in the first cycle to $80 \%$ in cycle 2 , and $90 \%$ in cycle 3 ".

\section{Research Methods}

This research was conducted in class XI of Senior High SchoOL Negeri 18 Medan academic year 2016/2017. The population in this study were all students of class XI MIPA Senior High School Negeri 18 Medan in the even semester academic year 2016/2017 which consists of 4 (four) classes. The sample of this study was all students of class XI Senior High SchoOL Negeri 18 Medan who were represented by two classes, namely class XI MIPA-2 as an experimental class who was given permission of cooperative learning model group investigation type and class XI
MIPA-3 as a control class who was given conventional learning model. Sampling in this study was taken randomly by using a random sampling technique.

This study included the type of quasiexperimental research and the research design used was the two group pretest-posttest design. The design of this study is shown in Table 1.

Table1. Two Group Pre-test and Post-test

\begin{tabular}{|c|c|c|c|}
\hline Class & Pre-test & Treatment & Post-test \\
\hline Experimental & $\mathrm{T}_{1}$ & $\mathrm{X}$ & $\mathrm{T}_{2}$ \\
\hline Control & $\mathrm{T}_{1}$ & $\mathrm{Y}$ & $\mathrm{T}_{2}$ \\
\hline
\end{tabular}

For information:

$\mathrm{T} 1=$ pre-test experimental class and control class.

$\mathrm{T} 2$ = post-test experimental class and control class.

$\mathrm{X}=$ Treatment given to the experimental class $\mathrm{Y}=$ Treatment given to the control class $\backslash$

\section{Results and Discussion}

\section{a. Research Result}

Based on the results of the pretest obtained, the average value of the experimental class pretest was 40.74 and the control class pretest score was 41.20. Furthermore, the experimental class and the control class were given different treatments. In the experimental class using a cooperative type GI model and in the control class using conventional learning. After the two classes were given treatment, each class was given a posture to see the difference due to being given different learning treatments. From the posttest data of the two classes, the average posttest scores for the experimental class were 75.14 and the mean scores of the control class posttest were 59.83 as shown in Figure 1:

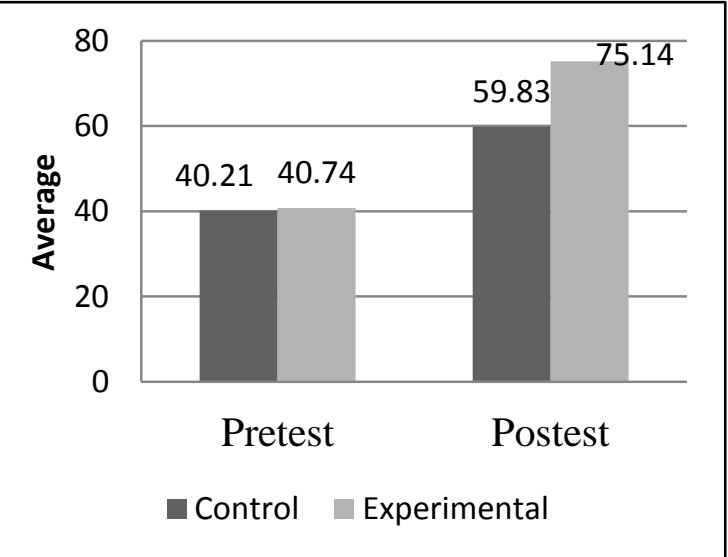


Figure1. Pretest and Postest of Experimental and Control Class

Based on the results of the normality test using the Lilliefors test for both samples, it was found that the pretest and posttest values were normally distributed as shown in Table 2 .

Table 2. Data Normality Test Results Pretests and Postests

\begin{tabular}{|c|c|c|c|}
\hline \multirow{2}{*}{ Class } & \multicolumn{2}{|c|}{ Pretest } & \multirow{2}{*}{ Conclusion } \\
\cline { 2 - 3 } & $\mathrm{L}_{\text {hitung }}$ & $\mathrm{L}_{\text {tabel }}$ & \\
\hline experimental & 0,0991 & 0,1610 & \multirow{2}{*}{ Normal } \\
\hline control & 0,0791 & 0,1910 & \\
\hline & \multicolumn{2}{|c|}{ Postest } & \multirow{2}{*}{} \\
\cline { 2 - 3 } & $\mathrm{L}_{\text {hitung }}$ & $\mathrm{L}_{\text {tabel }}$ & \\
\hline $\begin{array}{c}\text { Experimenta } \\
1\end{array}$ & 0,0958 & 0,1610 & \multirow{2}{*}{ Normal } \\
\hline Control & 0,0756 & 0,1910 & \\
\hline
\end{tabular}

Testing the homogeneity of pretest data and posttest data in the experimental class and control class was carried out by testing the similarity of two variances to find out whether the sample group came from a homogeneous population or not. The test results for the homogeneity of the data obtained are shown in Table 3.

Table 3. Homogeneity Test Results of the experimental and control class

\begin{tabular}{|c|c|c|c|c|}
\hline & Class & $\mathrm{F}_{\text {count }}$ & $\mathrm{F}_{\text {table }}$ & \\
\hline 1 & Pretest & 1,07 & 1,98 & Homogeneous \\
\hline 2 & Postest & 1,43 & 1,99 & Homogeneous \\
\hline
\end{tabular}

The results of the hypothesis test for posttest by using the t-test at a significant level $\alpha=0.05$, obtained $\mathrm{t}$ count $>\mathrm{t}$ table $(3.5730>$ 1.6755). Hypothesis test results on posttest results are shown in Table 4. Based on Table 4, obtained $t$ count $>t$ table, it can be concluded that there is the influence of cooperative learning model type group investigation on student learning outcomes.
Table 4. Calculation of Different Tests on experimental and control class

\begin{tabular}{|c|c|c|c|c|}
\hline & Class & $\mathrm{T}_{\text {count }}$ & $\mathrm{t}_{\text {table }}$ & Conclusion \\
\hline 1 & Experimental & 3,57 & 1,67 & $\begin{array}{c}\text { There is a } \\
\text { significant } \\
\text { difference }\end{array}$ \\
\cline { 1 - 2 } 2 & Control & &
\end{tabular}

\section{b. Discussion}

The results showed that there was the influence of cooperative learning model group investigation type on student learning outcomes in the subject matter of the Kinetic Gas Theory in Class XI Semester II Senior High School 18 Medan academic year 2016/2017. This result is indicated by the average posttest of the experimental class student learning outcomes of 75.14 higher than the average posttest of the control class student learning outcomes, which is 59.83 .

There is the influence of cooperative learning model type group investigation in the experimental class. This influence occurs because this learning model makes students able to assign submersions, learning objectives, collaboration in groups, communication in front of the class through percentages and draw conclusions themselves. Students will find and experience their own learning experiences by exchanging opinions with group discussion friends because students 'understanding can improve students' performance in learning that has an effect on learning outcomes.

The influence of cooperative learning model type group investigation on learning outcomes is supported by previous studies that have conducted research using the same learning model. Based on the results of a study conducted by Richardo (2015: 42), it was found that student learning outcomes using cooperative learning model group investigation type was better than using direct learning models. This happens because in the experimental class using cooperative type group investigation models, students are invited to discuss, interact between students so as to trigger students' creativity so as to improve student learning outcomes.

Cooperative model type investigation group is one form of cooperative learning model that emphasizes the participation and activities of students to search for their own material (information) lessons to be learned 
through available materials, for example from textbooks or students can search the internet. Students are involved since planning, both in determining topics and ways to learn them through investigation in discussion groups. In this experimental class students are required to give opinions, participate actively during discussions so that the effect on learning outcomes based on understanding during discussion in groups.

This is in accordance with the research of Lumbantoruan and Sirait (2016: 21) which states that the application of cooperative learning models of type group investigation can improve student learning outcomes in the subject matter of Temperature and Heat in SENIOR HIGH SCHOOL Negeri 1 Perbaungan. This is indicated by cognitive learning outcomes that increase significantly, namely before being given treatment the average pretest is 37.17 and after being given the treatment the posttest average was 70.75. Significant improvement of cognitive learning outcomes occurs between students who are taught by cooperative learning type group investigation with conventional learning.

The influence of cooperative learning model group investigation type also has an impact on differences in learning outcomes which increase the value of learning outcomes seen from the increase in student learning activities at each meeting. Furthermore, Hartoto (2016: 141) also stated that GI type cooperative learning has a positive impact on improving student learning achievement which is characterized by an increase in student learning completeness in each cycle, namely cycle I (72.5\%), cycle II $(80,0 \%)$, cycle III $(92.5 \%)$. The same is the case with Sari's previous research (2017: 31) which states that there are differences in physics learning outcomes taught by cooperative learning type group investigation and conventional learning.

The results of learning physics with cooperative learning models group investigation type are better than the results of learning physics with conventional learning. Student learning outcomes obtained in accordance with expected and experience changes after being given a cooperative learning model type of group investigation on physics learning. The cognitive learning outcomes of students who are taught by cooperative learning type group investigation are better because in the cooperative learning model the group investigation type students are involved in planning both the topics studied and how their investigation progresses. This model teaches students in good group communication and group processes (Wiratana et al. 2013: 3).

These learning outcomes are influenced by different treatments given to the experimental class. The experimental class was given the treatment of cooperative learning model type investigation group also assisted with the use of PhET media which facilitated the demonstration of material learning on the Kinetic Gas Theory. PhET media is effective in demonstrating the material of the kinetic theory of gas because it can demonstrate how particles move, how the temperature influences, the pressure in the movement of particles. The effectiveness of PhET media influences learning outcomes supported by Pujiyono's research, et al. (2016: 81), namely there is the effect of applying direct learning models that use Physics Education Technology (PhET) learning media on the learning outcomes of class X TITL on competency standards for applying electrical circuits in Vocational School 7 Surabaya. The average learning outcomes of the experimental class are 87.58 and the average value of the control class is 79.17. The use of PhET media can attract students' attention so that it can increase student interest and be motivated in learning that has an effect on learning outcomes.

The use of PhET simulation media as a learning media for Physics turned out to motivate students to study Physics. This can be seen from the data on the observation sheet, where more than $70 \%$ of students are actively and enthusiastically involved in learning. Another study that showed the influence of PhET media in improving learning outcomes, Wuryaningsih and Suharno (2014: 402) said that using the technology-based Physics learning model using PhET simulation media, students enjoyed the learning process better and the results showed a good improvement.

Nurhayati, et al., (2014: 6) revealed student learning outcomes taught by demonstration methods assisted by PhET animation media better than student learning outcomes using conventional methods. Learning using PhET animation media can foster student learning motivation in dynamic electrical material. Application of 
demonstration methods assisted by PhET animation media is effective in improving student learning outcomes in dynamic electrical material with the category of moderate effectiveness. Student learning outcomes taught by demonstration methods assisted by animation media PhET software are better than student learning outcomes using conventional methods. The occurrence of differences in student learning outcomes due to the demonstration method assisted by animation media PhET software can attract students' attention to learning in class and students not only imagine abstractly about the concept of dynamic electrical material, but students can see directly the concepts of dynamic electrical material taught by the teacher. Indirectly this affects the factors in the student namely the interests, attention and motivation of students to learn.

The use of PheT media can synergize physics learning and create active, creative and fun learning. Cooperative learning model type of group investigation combined with PheT media is intended so that learning objectives are expected to be carried out. The kinetic theory of gas material can be understood with the help of visual media, one of which is PheT media. Through the use of this media, students interact directly with the media and see directly through demonstrations displayed on PheT media.

The learning model has six phases that are carried out by researchers during their research in Senior High School 18 Medan. The first phase is the selection of topics. This phase, the researcher describes the subtopics which will be discussed in the subject matter of the Gas Kinetic Theory and sets the initial objectives of the discussion to students then instructs students to sit in groups of 5-6 students in a heterogeneous selected group. The second phase is cooperative planning, at this stage planning and explaining the learning procedures that will be carried out in group discussions and determining the objectives to be achieved after learning. The next phase is implementation, in this phase the researcher and each group carry out learning in accordance with predetermined procedures with the researcher briefly explaining the material to be studied. Each group discusses previously selected subtopics. Each group was given worksheet and held discussions, learning with guidance from researchers. The next stage is analysis and synthesis. Each group discusses the topic that has been chosen, then conducts an experiment, processes the data or material in accordance with the worksheet given to be contained in a summary summarizing all the material that will be discussed on the topic. The next phase is the percentage of the final product. Researchers give time for groups to display the results of group discussions in front of the class, each group and researcher listen carefully to the presentation of the results of the discussion from the groups that appear, after the presentation is conducted researchers and students (groups) conduct discussions, question and answer on material that has not been understood so the material studied can be clearly understood by students. The last stage is evaluating researchers and students reviewing the problem solving group discussion, how the participation of each group during learning takes place, evaluating individual performance in groups, adjusting objectives and implementing learning procedures with those planned at the beginning of learning and at this stage researchers provide evaluation tests for knowing students' understanding of the material that has been studied. After being given treatment in the experimental class than the two classes were given a posture to see the influence of cooperative model group investigation and conventional learning.

The cooperative learning group investigation model proved to be able to improve learning outcomes higher than conventional learning, but there were some shortcomings during the research, namely the researcher was not maximal in managing time so that all syntax was less effective during the learning process. The implementation in terms of controlling, directing students, disciplining an activity, the researchers themselves are still not adept at overcoming it, the result is that students waste more time just telling stories in groups, time that might be used to discuss questions that are less than optimal. The use of research instruments in this study on the Bloom taxonomy is only to the $\mathrm{C} 4$ level so that the research instruments used are still relatively easy because they do not use C5 and C6. Research should use instruments ranging from levels C1-C6 to streamline the results of research, especially student learning outcomes. 


\section{Conclusion}

Based on the results of the study, the author presents the following conclusions:

1. Student learning outcomes after being treated using cooperative learning models investigation group type has increased indicated by posttest average value 75.14.

2. Student learning outcomes using conventional learning are lower than the class given the cooperative learning model group investigation type.

3. The results of the study showed that there was a significant effect using cooperative learning type group investigation of student learning outcomes in the subject matter of the Kinetic Gas Theory in class XI Senior High SchooL Negeri 18 Medan.

\section{Suggestion}

Based on the results of the research and the conclusions above, as a follow-up of this research, several things are suggested as follows:

1) For the next researcher, there is another alternative in making time-efficient during learning.

2) The use of instruments is considered again the completeness of the C1-C6 cognitive domain in order to achieve the expected research.

\section{References}

Afdalita, E dan Purwanto, (2015), Pengaruh Model Pembelajaran Kooperatif Tipe Group Investigation (GI) terhadap Hasil Belajar Fisika pada Materi Pokok Listrik Dinamis Di SMA Amir Hamzah Medan, Jurnal Inpafi 3(1):196-201.

Hartoto, T, (2016), Model Pembelajaran Kooperatif Tipe Group Investigation (GI) Meningkatkan Aktivitas dan Hasil Belajar Sejarah, Jurnal Historia 4(2):131-142.

Joyce, B, Weil, M. dan Calhoun, E, (2011), Models of Teaching, Yogyakarta, Pustaka Pelajar.

Kamaruddin, T, Cut M, (2016), Penerapan Media Virtual PhET untuk
Meningkatkan Hasil Belajar Fisika pada Siswa SMAN 4 Banda Aceh, Jurnal Fisika Edukasi (JFE) 3(2):33-39.

Lumbantoruan, D dan Sirait, M, (2016), Pengaruh Model Pembelajaran Kooperatif Tipe Group Investigation (GI) untuk Meningkatkan Hasil Belajar Siswa pada Materi Pokok Suhu dan Kalor, Jurnal Inpafi 4(4):15-22

Nurhayati, Fadilah, S dan Mutmainnah., (2014),

Penerapan Metode Demonstrasi Berbantu Media Animasi Software Phet terhadap Hasil Belajar Siswa dalam Materi Listrik Dinamis Kelas X Madrasah Aliyah Negeri 1 Pontianak, Jurnal Pendidikan Fisika dan Aplikasinya (JPFA) 4(2):1-7.

Pujiyono, Debora N.S dan Sudarmi, M, (2016), Desain Pembelajaran dengan Menggunakan Media Simulasi PhET (Physics Education and Technology) Pada Materi Medan Listrik, Unnes Physics Education Journal(UPEJ) 5(1):70-82.

Purwanto, (2014), Evaluasi Hasil Belajar, Yogyakarta, Pustaka Pelajar.

Richardo, R, (2015), Eksperimentasi Model Pembelajaran Kooperatif Tipe Investigasi Kelompok (Group Investigation) terhadap Hasil Belajar Matematika Berdasarkan Gaya Belajar Siswa, Jurnal Ilmiah Edu Research 4(1):35-42.

Sari, E, (2017), Pengaruh Model Pembelajaran Kooperatif Tipe Group Investigation terhadap Hasil Belajar Fisika Ditinjau dari Kemampuan Berpikir Logis, Jurnal Pendidikan Fisika 6(1):27-32.

Sudjana, (2008), Metode Statistik, Bandung, Tarsito.

Sumargo, E dan Yuanita, L, (2014), Penerapan Media Laboratorium Virtual (PhET) pada Materi Laju Reaksi dengan Model Pengajaran Langsung, Unesa Journal of Chemical Education 3(1):119-133. 
Trianto, (2010), Mendesain Model Pembelajaran Inovatif-Progresif, Jakarta, Kencana.

Wiratana, I K, I Wayan Sadia dan Ketut Suma, (2013), Pengaruh Model Pembelajaran Kooperatif Tipe Investigation Kelompok (Group Investigation) terhadap Keterampilan Proses dan Hasil Belajar Siswa SMP. Journal Program Pascasarjana Universitas Pendidikan 3(1):1-12.

Wuryaningsih, R dan Suharno, (2014), Penerapan Pembelajaran Fisika dengan Media Simulasi PhET pada Pokok Bahasan Gaya untuk Meningkatkan Hasil Belajar Siswa Kelas VIIIA SMPN 6 Yogyakarta, Prosiding Pertemuan Ilmiah XXVIII HFI Jateng \& DIY 4(1):400-402.

Yuafi, MED dan Endryansyah, (2015), Pengaruh Penerapan Media Pembelajaran PhET (Physics Education Technology) Simulation terhadap Hasil Belajar Siswa Kelas X TITL pada Standar Kompetensi Mengaplikasikan Rangkaian Listrik Di SMKN 7 Surabaya, Jurnal Pendidikan Teknik Elektro 4(2):407-414.' 